Jurnal Pendidikan Ekonomi: Jurnal Ilmiah Ilmu Pendidikan, Ilmu Ekonomi, dan Ilmu Sosial

ISSN 1907-9990 | E-ISSN 2548-7175 $\mid$ Volume 11 Nomor 1 (2017)

\title{
PERILAKU WIRAUSAHA PEDAGANG ETNIS CINA DI JALAN SAMANHUDI KABUPATEN JEMBER
}

\author{
Aini Nur Rohmah ${ }^{1}$, Joko Widodo ${ }^{1}$, Sutrisno Djaja ${ }^{1}$ \\ ${ }^{1}$ Program Studi Pendidikan Ekonomi, Fakultas Keguruan dan Ilmu Pendidikan, Universitas Jember
}

\begin{abstract}
This study aims to describe how the entrepreneur behavior of ethnic Chinese traders in Jalan Samanhudi Jember regency. Limited employment and increasingly intense competition among job seekers make some of people in Jalan Samanhudi Jember work as entrepreneurs. Formerly Jalan Samanhudi was one of Chinatown area in Jember Regency. Actually, there are many ethnic Chinese traders who trade in their shop. Through observations conducted by researchers they found that ethnic Chinese traders in Jalan Samanhudi Jember regency are able to maintain their business in a long time and quite successful in the field of trading although they are from the wandering people overseas. Those characteristics of entrepreneurial behavior shown by ethnic Chinese traders are not easy to despair, not to let go of opportunities, keeping promises, trying to convince customers during trading and have extremely good endurance and enthusiasm. Data collection methods used consisted of observation, interview and document methods. The analytical method used is descriptive qualitative. The result of this study indicate that the entrepreneur behavior of ethnic Chinese traders in Jalan Samanhudi Jember regency is very strong in running their business.
\end{abstract}

Keywords: Enterpreneur Behavior, Ethnic Chinese

\section{PENDAHULUAN}

Etnis cina merupakan salah satu etnis yang memiliki kebiasaan merantau ke negeri orang. Mereka merantau dengan berdagang untuk memenuhi kebutuhan hidupnya di tanah perantauan. Keberagaman etnis yang merantau di Indonesia mereka mempunyai perbedaan dalam hidup dan berkembang secara alami. Begitu pula dengan etnis cina. Mereka memiliki perilaku dan kebudayaan tersendiri dalam berdagang. Menurut Seng (2008: 15) ada beberapa ciri-ciri perilaku pedagang etnis cina dalam menjalankan usaha dagangnya, perilaku tersebut diantaranya tidak mudah putus asa, tidak melepas peluang, menepati janji, berusaha meyakinkan pelanggan selama menjalankan urusan dagang dan memiliki daya tahan dan semangat juang yang tinggi.

Menurut Dirlanudin dalam Rina (2010: 10) Perilaku menunjukkan pola tindakan yang diperlihatkan seseorang dan merupakan hasil kombinasi pengetahuan sikap, dan keterampilannya. Sedangkan pengertian wirausaha menurut Soegoto (2014: 26) Wirausaha atau Entrepreneur adalah orang yang berjiwa kreatif, inovatif, mandiri, percaya diri, ulet, dan tekun, rajin, disiplin, siap menghadapi risiko, meraih peluang, pandai mengelola sumber daya, dalam membangun, mengembangkan, memajukan dan menjadikan usaha atau perusahaannya unggul. Jadi yang dimaksud dengan perilaku wirausaha adalah tindakan atau kebiasaan seseorang yang didasarkan dalam diri yang ditunjukkan pada pengetahuan, sikap dan keterampilan untuk melakukan suatu usaha secara inovatif, kreatif, berani mengambil resiko dan berdaya saing.

Menurut Oei (2008: 7) kebanyakan orang cina dalam berwirausaha adalah hasil warisan dari keluarga sehingga hanya anak dan keturunan yang dapat menikmati keberhasilan dan orang lain tidak dapat ikut campur didalamnya. Warisan budaya tersebut dilakukan secara turuntemurun dan pada akhirnya akan membentuk pola perilaku yang berbeda dengan etnis lainnya. Etnis cina memiliki jiwa yang sangat tinggi dalam berdagang. Bagi etnis cina perdagangan 
sudah menjadi pekerjaan utama bagi mereka. Perdagangan adalah kegiatan yang menjanjikan suatu keuntungan bagi yang menjalankan suatu usaha dagang tersebut.

Jalan Samanhudi merupakan salah satu jalan yang dahulu pusat perdagangan sekaligus pusat hiburan masyarakat yang terletak di kompleks Pasar Tanjung hingga Jalan Samanhudi Kabupaten Jember. Di tempat itulah, perekonomian Jember digerakkan oleh masyarakat cina. Di Jalan Samanhudi banyak toko-toko yang berdiri milik pedagang etnis cina, dengan tokotoko tersebut menjadi saksi bahwa kawasan pecinan terletak di Jalan Samanhudi. Seiring dengan banyaknya pesaing antar pedagang yang ada di Jalan Samanhudi Kabupaten Jember, pedagang etnis cina terbukti mampu mempertahankan eksistensinya ditengah persaingan yang ketat. Namun pada kenyataannya meskipun banyak pesaing toko milik pedagang etnis cina masih ramai dengan pembeli dan dapat bertahan dibidang perdagangan. Hal ini dilihat dari perilaku pedagang etnis yang loyal kepada pembeli. Kesigapan pedagang dalam melayani konsumen betujuan agar para konsumen tersebut tidak berpindah dan tetap membeli barangbarang di toko tersebut.

Berdasarkan latar belakang di atas maka permasalahan dalam penelitian ini adalah bagaimanakah perilaku wirausaha pedagang Etnis Cina di Jalan Samanhudi Kabupaten Jember. Berdasarkan rumusan masalah tersebut maka tujuan penelitian ini adalah untuk mendeskripsikan bagaimana perilaku wirausaha pedagang Etnis Cina di Jalan Samanhudi Kabupaten Jember.

\section{METODE PENELITIAN}

Jenis penelitian ini merupakan penelitian deskriptif yang menggunakan pendekatan kualitatif. Peneliti menggunakan deskriptif kualitatif sebab peneliti ingin menggambarkan perilaku wirausaha pedagang Etnis Cina di Jalan Samanhudi Kabupaten Jember. Penentuan lokasi penelitian menggunakan metode Purposive Area dengan menentukan lokasi Jalan Samanhudi di Kabupaten Jember sebagai lokasi penelitian, sedangkan subyek dalam penelitian ini adalah pedagang etnis cina yang berdagang di Jalan Samanhudi Kabupaten Jember berjumlah 31 pedagang dimana informan utama dalam penelitian ini adalah pedagang etnis cina dan informan pendukung dalam penelitian ini adalah pelanggan dan karyawan dari pedagang etnis cina. Jenis dan sumber data yang digunakan adalah data primer dan data sekunder. Metode pengumpulan data menggunakan metode wawancara, observasi, dan dokumen. Dan metode analisis data yang digunakan adalah kegiatan reduksi data (data reduction), penyajian data (data display), dan penarikan kesimpulan dan verifikasi (drawing conclusion and verification).

\section{HASIL DAN PEMBAHASAN}

\section{Hasil Penelitian}

Berdasarkan hasil penelitian diketahui bahwa terdapat ciri-ciri perilaku wirausaha pedagang etnis cina di Jalan Samanhudi Kabupaten Jember sebagai berikut:

1. Tidak mudah putus asa

Pedagang etnis cina di Jalan Samanhudi Kabupaten Jember dalam menjalankan usahanya mengalami masalah dan kendala-kendala dalam berdagang. Akan tetapi mereka dapat mengatasi masalah tersebut dan dapat mempertahankan usahanya selama bertahuntahun. Mereka rata-rata menjalankan usahanya sudah lebih dari 5 tahun. Masalah-masalah 
yang ada dapat mereka hadapi dengan baik. Mereka tidak pernah berputus asa dan mampu bangkit kembali dalam menjalankan usahanya. Hal tersebut sesuai dengan pernyataan dari Bapak Endi selaku salah satu informan utama penelitian sebagai berikut:

"Selama berdagang saya sering mengalami kerugian biasanya mengenai barang yang rusak mengakibatkan barang tidak laku jual, barang yang sudah ketinggalan trend dan pernah ada piutang yang tidak dibayar. Bangkit dari masalah tersebut saya melakukan apa saja yang dapat dikerjakan dan melakukan apapun yang terbaik dalam berwirausaha"(E,50 Tahun).

Hasil penelitian yang diperoleh peneliti bahwa pedagang-pedagang etnis cina di Jalan Samanhudi Kabupaten Jember ketika mengalami masalah dan kendala dalam berdagang mereka dapat bangkit dari masalah tersebut. Hal tersebut tidak membuat mereka berputus asa dan terpuruk. Mereka segera bangkit kembali melanjutkan usahanya. Bagi mereka masalah dan kendala tersebut dijadikan sebagai pengalaman dan menjadi semakin lebih baik kedepannya.

2. Tidak melepas peluang

Seorang wirausaha memiliki jiwa dalam berbisnis yang mumpuni, salah satunya mereka dapat memanfaatkan peluang waktu dan peluang usaha baru dalam berdagang. Dalam memanfaatkan peluang usaha tersebut mereka memiliki usaha sampingan yang dapat menambah pendapatan. Salah satu ungkapan dari Bapak Yahya Teguh beliau merupakan pedagang etnis cina yang berjualan emas. Selain berjualan emas Bapak Yahya Teguh juga berjualan elpiji dan bahan pencerah emas. Hal ini terbukti bahwa hasil wawancara yang dilakukan oleh peneliti dengan karyawan Bapak Yahya Teguh yaitu Bapak Nur Hadi sebagai berikut:

"Toko yang dimiliki Bapak Yahya Teguh ini buka setiap hari dari jam 09.0017.00. Karena kalau terlalu pagi konsumen belum banyak yang membeli. Pemanfaatan waktu istirahat sebaik mungkin agar tidak membuang waktu saya lakukan. Selain berjualan emas beliau juga berjualan elpiji dan bahan pencerah emas. Adanya peluang usaha dapat dimanfaatkan beliau dengan sebaik mungkin. Karena di Jalan Samanhudi satu-satunya yang berjualan bahan pencerah emas adalah beliau. Dari situlah pendapatan yang diperoleh beliau dapat bertambah"'(N, 42 Tahun).

Wawancara yang dilakukan oleh peneliti terhadap beberapa Informan utama, bahwa pedagang etnis cina mampu memanfaatkan peluang waktu dan peluang usaha dengan baik. Meskipun mereka dari masyarakat perantauan akan tetapi dalam berwirausaha mereka tergolong cukup berhasil. Mereka mampu memanfaatkan waktu sebaik mungkin. Bagi mereka waktu adalah segalanya dan mereka juga mampu memanfaatkan peluang usaha baru. Adanya peluang usaha yang lebih menjanjikan mereka lakukan demi memperoleh hasil yang diinginkan.

3. Menepati Janji

Sebagai pedagang harus jujur dan dapat dipercaya. Menanamkan kepercayaan kepada konsumen sangat diperlukan untuk mendukung keberhasilan dalam berwirausaha. Menepati janji adalah salah satu perilaku yang dapat menjadi pendukung suatu usaha. Akan tetapi banyak para pedagang yang hanya memberikan janji-janji belaka, dan mereka tidak 
takut akan akibatnya. Banyak pebisnis atau pedagang yang sering membuat janji belaka terhadap suatu hal kepada konsumen atau relasi bisnisnya. Hal ini sangat dihindari oleh para pedagang etnis cina. Karena dengan mengingkari janji akan menghilangkan rasa kepercayaan seseorang kepadanya. Dan jika tidak ada orang yang percaya lagi, maka usaha yang dijalankan akan menuju kebangkrutan. Salah satu informan pendukung dalam penelitian ini adalah Ibu Sulihati beliau adalah pelanggan dari Bapak Sutrisno Budiarjo.

"Saya senang kulakan pakaian di Toko Indomakmur karena pedagangnya ramah dan sabar serta pakaian yang dijual bervariasi modelnya. Kalau kulakan baju saya percaya di toko Indomakmur karena harga yang diberikan harga grosir jadi terkesan murah. Selain itu barang yang dijual memiliki kualitas yang bagus sesuai harganya dan ketika pelanggan memesan barang, mereka mampu mencarikan sesuai keinginan pelanggan dan mendatangkan secara tepat waktu”(S, 32 Tahun).

Pedagang etnis cina mampu menjaga loyalitas dengan konsumennya. Mereka dapat membuat para konsumen untuk mempunyai kepercayaan terhadapnya dengan menepati janji ketika konsumen memesan barang yang diinginkan. Kepercayaan yang dimiliki oleh konsumen membuat, pedagang mempunyai banyak pelanggan. Hal tersebut dapat mempengaruhi kondisi usaha pedagang yang semakin meningkat, karena segala pekerjaan yang dilakukan dengan maksimal nantinya akan memperoleh hasil yang maksimal pula.

4. Berusaha menyakinkan pembeli selama menjalankan urusan dagang

Sebagai pedagang menumbuhkan keyakinan kepada konsumen sangat diperlukan. Keyakinan yang diberikan pedagang kepada konsumen membuat mereka percaya bahwa pedagang memberikan yang terbaik kepadanya. Keuntungan tersebut membuat pedagang mempunyai banyak pelanggan. Demikian halnya dengan pedagang etnis cina di Jalan Samanhudi Kabupaten Jember bahwa rata-rata mereka mempunyai pelanggan. Hal ini terbukti bahwa toko yang dimiliki pedagang etnis cina jarang yang sepi. Sebagai pedagang mereka melayani konsumen dengan baik dan ramah. Bahkan mereka menganggap bahwa konsumen sebagai raja. Hal tersebut mereka lakukan agar konsumen yang membeli merasakan kepuasan. Salah satu informan utama penelitian yaitu Bapak Yahya Teguh dalam berdagang beliau memberikan kualitas emas yang bagus tergantung dari tingkat harga yang dimiliki konsumen. Dari kepercayaan tersebut membuat pelanggan yakin dengan keyolalitasan pedagang terhadap konsumennya Hal ini sesuai dengan pernyataan dari Bapak Yahya Teguh.

"Dalam berdagang saya menjalin hubungan dan melayani para konsumen dengan baik. Untuk menghadapi pembeli harus murah senyum dan harus sabar yang terpenting pembeli suka dan puas terhadap pelayanan yang kami berikan. Cara yang saya lakukan untuk menumbuhkan kepercayaan kepada para konsumen adalah dengan memberikan kualitas barang yang bagus sesuai keinginan dan tingkat harga yang konsumen miliki" (Y, 64 Tahun).

Dapat diketahui bahwa pedagang etnis cina di Jalan Samanhudi Kabupaten Jember untuk meyakinkan kepada konsumen mereka memberikan pelayanan yang baik, ramah, sabar, dan memberikan kualitas barang yang sesuai keinginan pembeli dan memberikan 
hadiah pada hari-hari tertentu. Kepercayaan yang dimiliki oleh konsumen tersebut membuat pedagang mempunyai banyak pelanggan dan menambah keuntungan dalam berdagang.

5. Memiliki daya tahan dan semangat juang yang tinggi

Daya tahan dan semangat juang yang tinggi sangat dibutuhkan pedagang dalam mempertahankan usahanya. Mereka harus selalu mempunyai perilaku tersebut agar usahanya lancar. Dengan daya tahan dan semangat juang yang tinggi akan memotivasi diri untuk selalu optimis. Pedagang etnis cina di Jalan Samanhudi Kabupaten Jember pada umumnya setiap berdagang pasti mempunyai pesaing-pesaing dari antar pedagang lainnya. Akan tetapi mereka menganggap bahwa para pesaing sudah menjadi hal yang wajar dalam mengahadapi lika-liku berdagang. Mental kuat yang dimiliki oleh pedagang etnis cina membuat mereka berani dalam menghadapi resiko-resiko yang dihadapinya didepan mata. Ungkapan informan utama dari Bapak Fredi, beliau sudah lama berdagang di Jalan Samanhudi Kabupaten Jember sekitar 35 Tahun. Beliau mempunyai semangat dan daya tahan yang tinggi dalam berdagang.

"Semangat dalam berdagang yang saya miliki adalah ketelatenan. Telaten dalam menghadapi pelanggan maupun dengan pesaing dagang. Cara yang saya lakukan berbeda dengan pesaing adalah dengan memberikan harga grosiran dan pelayanan yang bagus kepada pelanggan agar mereka terkesan puas ketika membeli di toko saya"(F, 56 Tahun).

Untuk dapat bertahan pedagang etnis cina memiliki semangat dan daya tahan yang tinggi dalam berdagang. Pedagang etnis cina di Jalan Samanhudi Kabupaten Jember tersebut menyukai pekerjaan sebagai pedagang, sehingga mereka melakukan pekerjaan tersebut dengan maksimal dan bersemangat tanpa adanya paksaan dalam melakukannya. Segala pekerjaan yang dilakukan dengan maksimal akan memperoleh hasil yang maksimal pula. Dalam menghadapi para pesaing mereka juga bersaing dengan sehat dan saling menghormati meskipun banyak pesaing yang dari beberapa macam etnis.

\section{Pembahasan}

Berdasarkan data yang diperoleh peneliti dari subyek penelitian yaitu pedagang etnis cina di Jalan Samanhudi Kabupaten Jember menunjukkan bahwa mereka memiliki perilaku dalam berwirausaha yang digunakan untuk menjalankan usaha dagang mereka. Perilaku yang mereka miliki digunakan untuk bertahan lama berdagang di Jalan Samanhudi Kabupaten Jember. Rata-rata mereka telah berdagang lebih dari 5 Tahun. Perilaku yang mereka miliki membuat mereka menjadi pedagang yang cukup sukses di Jalan Samanhudi Kabupaten Jember. Menurut Seng (2008: 152) pedagang etnis cina memiliki ciri-ciri perilaku dalam berwirausaha yang membantu mereka dalam mencapai kesuksesan. Ciri-ciri perilaku tersebut antara lain tidak mudah putus asa, tidak melepas peluang, menepati janji, berusaha meyakinkan pembeli selama menjalankan urusan dagang dan memiliki daya tahan dan semangat juang yang tinggi.

Berdasarkan penelitian yang telah dilakukan oleh peneliti dapat diketahui bahwa pedagang etnis cina di Jalan Samanhudi Kabupaten Jember rata-rata mereka dapat mempertahankan usahanya meskipun mereka berasal dari masyarakat perantauan. Pasang surut dunia perdagangan telah dirasakan oleh pedagang etnis cina dan peristiwa tersebut sudah menjadi hal biasa yang dijalani sebagai seorang pedagang. Dengan berbagai macam masalah 
yang dihadapi para pedagang menjadikan suatu motivasi untuk lebih baik dan maju dalam menjalankan kegiatan perdagangannya.

Masalah-masalah yang dihadapi oleh pedagang etnis cina salah satunya adalah penurunan omzet dan berbagai macam resiko dalam berdagang. Dalam dunia perdagangan memang banyak resiko yang dihadapi, akan tetapi dengan masalah tersebut bagi pedagang etnis cina mereka mampu menghadapi resiko tersebut dengan baik. Masalah dan kendala yang terjadi tidak membuat mereka berputus asa dan langsung terpuruk begitu saja. Perilaku tidak mudah putus asa merupakan perilaku seseorang yang selalu optimis dan menganggap dirinya berhasil dalam menghasilkan sesuatu harapan dan cita-cita (Blogspot.co.id: 2014). Dengan masalah yang dialami para pedagang tersebut menjadikan suatu pembelajaran dan pengalaman untuk maju dan berkembang dalam berwirausaha. Mereka melanjutkan keterpurukan mereka, namun dapat bangkit kembali dan tetap menjalankan usaha dagangannya. Perilaku tidak mudah putus asa yang mereka miliki mampu bertahan berdagang di Jalan Samanhudi Kabupaten Jember hingga sampai saat ini.

Menurut Moris dalam David (2015: 63) sebagai seorang wirausaha harus dapat mengambil tindakan dalam jangka waktu yang singkat serta memanfaatkan peluang usaha dengan cepat. Dengan memanfaatkan waktu sebaik mungkin mereka dapat mengetahui bahwa para konsumen datang pada waktu tertentu. Tidak hanya itu pedagang etnis cina juga memanfaatkan peluang usaha baru yang dapat mereka jalankan. Bagi mereka kesempatan mencari rezeki tidak boleh disia-siakan. Kesempatan tersebut sangat menguntungkan bagi pedagang dan usahanya. Pedagang etnis cina menggunakan kemampuan yang maksimal dalam diri mereka untuk mencapai kehidupan yang lebih baik.

Setiap pedagang memiliki cara atau perilaku wirausaha menepati janji kepada konsumen termasuk pedagang etnis cina di Jalan Samanhudi Kabupaten Jember. Perilaku menepati janji merupakan salah satu perilaku manusia yang baik dan dapat mengantarkan untuk mencapai kesuksesan dengan upaya yang sudah dilakukan (www.academia.edu). Perilaku tersebut ditunjukkan oleh pedagang dalam menghadapi pesanan pelanggan. Mereka mempunyai komitmen yang kuat untuk melayani kebutuhan pelanggan tersebut dan bertujuan untuk mempertahankan loyalitas pelanggan maupun dengan pedagang lainnya yang terjalin urusan hutang maupun piutang. Perilaku menepati janji dapat menumbuhkan rasa kepercayaan antara konsumen kepada pedagangnya. Dengan menanamkan rasa kepercayaan tersebut maka, pedagang akan mempunyai banyak pelanggan. Dengan banyaknya pelanggan yang dimiliki oleh pedagang dapat menjadi faktor kesuksesan pedagang untuk mencapai keberhasilan.

Sebagai pedagang menjaga hubungan yang baik dengan konsumen adalah hal yang harus dijalani. Menurut Zaqeus (2016: 96) pedagang harus bisa menarik perhatian, minat, keinginan dan tindakan konsumen untuk membeli. Pedagang harus berusaha menyakinkan pembeli akan manfaat dan kegunaan produk yang dijual dengan tujuan agar pedagang dapat merealisasikan keinginan dari konsumennya. Pedagang etnis cina di Jalan Samanhudi Kabupaten Jember melayani konsumen dengan baik dan sepenuh hati. Bagi mereka konsumen adalah raja, mereka yang membawa keberuntungan bagi pedagang. Setiap pedagang mencari pelanggan yang banyak untuk meluaskan jaringan bisnis usaha yang mereka jalankan. Sebagai pedagang harus mempunyai perilaku dapat meyakinkan pembeli dalam urusan dagang. Perilaku tersebut dapat ditunjukkan dengan memberikan keyakinan kepada pembeli mengenai barang- 
barang yang ditawarkan dengan memiliki kualitas yang bagus, sehingga pembeli akan merasakan kepuasan dengan barang yang mereka butuhkan. Dengan keyakinan yang dimiliki pelanggan kepada pedagang etnis cina membuat banyak konsumen yang membeli di toko tersebut. Keyakinan yang dimiliki pelanggan berarti mereka puas akan pelayanan maupun barang yang dijual oleh pedagang tersebut.

Menurut Hendro (2011: 174) sumber energi yang dibutuhkan dalam berwirausaha adalah semangat yang tinggi. Semangat tersebut dapat menjadikan motivasi untuk berwirausaha. Perilaku tersebut ditunjukkan oleh pedagang etnis cina di Jalan Samanhudi Kabupaten Jember dalam menghadapi pesaing-pesaing antar pedagang. Mereka memang bersaing dibidang perdagangan akan tetapi tidak pernah terjadi konflik diantara mereka. Selama ini mereka hidup berdampingan dan rukun. Hal tersebut mereka lakukan agar mereka dapat diterima dan dipercaya berdagang di Jalan Samanhudi Kabupaten Jember oleh masyarakat pribumi. Semangat tinggi yang mereka miliki dipengaruhi oleh faktor dorongan yang kuat dari dalam maupun dari luar. Dengan motivasi yang dimiliki oleh pedagang tersebut akan menumbuhkan perilaku daya tahan yang kuat untuk mempertahankan usahanya menjadi maju dan berkembang.

\section{KESIMPULAN DAN SARAN}

\section{Kesimpulan}

Hasil penelitian dari analisis data, dapat ditarik kesimpulan bahwa banyaknya para pedagang dari berbagai macam etnis di Jalan Samanhudi Kabupaten Jember membuat banyak persaingan dalam berdagang. Akan tetapi dengan persaingan tersebut pedagang etnis cina mempunyai perilaku dalam berwirausaha untuk dapat mempertahankan usahanya. Perilaku wirausaha tersebut adalah perilaku tidak mudah putus asa, dapat ditunjukkan dalam menghadapi penurunan omzet dan berbagai macam resiko dalam berdagang. Perilaku tidak melepas peluang, dapat ditunjukkan dengan membuka dan menutup toko, mereka memanfaatkan waktu sebaik mungkin untuk mengetahui bahwa pada saat tersebut banyak dan tidaknya konsumen yang akan membeli dan mereka juga memanfaatkan peluang usaha yang baru meskipun mereka sudah mempunyai usaha yang ada.

Perilaku menepati janji, dapat ditunjukkan oleh pedagang dalam menghadapi pesanan pelanggan. Perilaku berusaha menyakinkan pembeli selama menjalankan urusan dagang dapat ditunjukkan dengan memberikan keyakinan kepada pembeli mengenai barang-barang yang ditawarkan dengan memiliki kualitas yang bagus, sehingga pembeli akan merasakan kepuasan dengan barang yang mereka butuhkan. Dan Perilaku memiliki daya tahan dan semangat juang yang tinggi, dapat ditunjukkan dalam menghadapi pesaing-pesaing antar pedagang.

\section{Saran}

Adapun saran yang dapat diberikan kepada beberapa pihak, antara lain: (1) Bagi pedagang etnis cina di Jalan Samanhudi Kabupaten Jember, hendaknya perlu meningkatkan perilaku dalam berwirausaha, (2) Bagi konsumen, hendaknya dapat memberikan masukan kepada para pedagang mengenai usaha mereka guna terus meningkatkan usaha yang dijalankan tersebut dan (3) Bagi peneliti selanjutnya, hendaknya dapat mengembangkan penelitian ini dengan penelitian yang lebih menarik dan lebih luas. 


\section{DAFTAR BACAAN}

Academia.edu. di akses di https://www.academia.edu/19043875/Menepati_Janji. Pada tanggal 20 Maret 2017 pukul 08.16.

Afrizal, M.A. Prof. Dr. 2015. Metode Penelitian Kualitatif. Jakarta, PT Raja Grafindo Persada.

Blogspot.co.id di akses di http://postinglengkap.blogspot.co.id/2014/04/pengertian-putus-asapenyebab-putu-asa.html. Pada tanggal 20 Maret 2017 pukul 06.19

Fauzah, Rina. 2013. Perilaku Kewirausahaan Pedagang Warung Tenda Pecel Lele Kerukunan Keluarga Besar Siman Jaya (KKBSJ) di Jakarta. (Skripsi) Bogor: Departemen Agribisnis, Fakultas Ekonomi dan Manajemen, Institut Pertanian Bogor.

Hendro M,M. Ir. 2011.Dasar-dasar Kewirausahaan. Jakarta: Erlangga.

Kodrat, David S dkk. 2015. Entrepreneurship Sebuah Ilmu. Jakarta: Erlangga.

Oie, Istijanto. 2008. Rahasia Sukses Toko Tionghoa. Jakarta: Gramedia Pustaka Utama.

Seng, Ann Wang. 2008. Rahasia Bisnis Orang Cina. Makassar, PT Mizan Publika.

Soegoto, Dr. Ir. Eddy Soeryanto.2014. Entrepreneurship Menjadi Pebisnis Ulung. Jakarta, PT Gramedia.

Zaqeus, Edy. 2016. Rahasia Sukses Entrepreneur. Jakarta: Salemba Empat. 